\title{
Peningkatan Hasil Belajar Siswa Dalam Pembelajaran IPA Berbasis Mind Map di kelas III SD Negeri 07 Situjuh Gadang, Kabupaten Lima Puluh Kota
}

\author{
Ira Dewi Hariani ${ }^{1}$ \\ ${ }^{1}$ SDN 07 Situjuh Gadang, Kec. Situjuah Limo Nagari
}

\begin{abstract}
Abstratc: This research is motivated by the desire to improve the learning process that has been done with the aim of improving student learning outcomes by applying a Mind Map-based learning model to science subjects. This research is a classroom action research (PTK) using a qualitative approach conducted on students of class III at SD Negeri 07 Situjuh Gadang, Lima Puluh Kota. The problem being solved stems from the problem of practical learning in class in a professional manner. The procedure of conducting this research consists of two cycles that follow the basic principles of general classroom action research. The instrument of this research is the TK / SD supervisor as the observer and the writer himself as the planner and executor of learning in the classroom. The data obtained in this study were analyzed using qualitative data analysis which was analyzed starting from data collection to all data collected. From the results of data processing it was found that the application of Mind Map-based learning to third grade students at SD Negeri 07 Situjuah Gadang on natural science subjects could improve student learning outcomes.
\end{abstract}

Keyword: Mind Map-based learning model

This is an open access article distributed under the Creative Commons Attribution License, which permits
unrestricted use, distribution, and reproduction in any medium, provided the original work is properly
cited. (C) 2020 by author

\section{PENDAHULUAN}

Dalam melaksanaan pembelajaran, sejatinya guru haruskan memakai metode yang beragam dan sisesuaikan dengan materi yang akan diberikan, sehingga siswa dapat memahami materi yang diberikan guru. Namun dalam prakteknya, peneliti hanya melakukan satu metode pembelajaran untuk semua materi pelajaran, yaitu metode ceramah. Dimana dalam pelaksanaannya guru lebih aktif sedangkan siswa hanya sebagai pendengar yang baik dalam belajar, sehingga dalam pembelajaran siswa hanya menjadi objek. Setelah selesai menerangkan, guru mendiktekan ringkasan materi pembelajaran untuk dicatat siswa pada buku catatannya masing-masing. Akibatnya dari cara pembelajaran yang telah penulis lakukan berdampak negatif terhadap proses dan hasil belajar, dalam proses pembelajaran, banyak sekali kendala yang penulis temui, seperti: ada siswa yang meribut, mengantuk, berbicara dengan temannya, ada yang iseng mengganggu siswa lain yang sedang belajar, pokoknya ada saja yang mereka lakukan yang mengganggu proses pembelajaran. Seakan-akan pembelajaran yang disajikan oleh guru tidak membuat mereka tertarik bahkan mereka terlihat sangat bosan dalam mengikutinya.

Untuk hasil belajar, nilai yang diperoleh tidak sesuai dengan yang diinginkan. Ini terbukti pada hasil penilaian proses hasil belajar untuk mata pelajaran Ilmu Pengetahuan Alam , pada semester I tahun pelajaran 2018/2019 untuk kelas III Sekolah Dasar (SD) 07 SitujuhGadang, peneliti merasa kecewa karena sebagian besar dari siswa tidak tuntas dalam UAS, KKM yang 
telah ditetapkan untuk mata pelajaran ini yaitu 75 tidak berapa orang yang mencapai atau melebihinya.

Bertolak dari masalah di tersebut, peneliti merasa perlu untuk memperbaiki proses pembelajaran yang telah dilakukan agar masalah tersebut tidak menyebabkan terjadinya masalahmasalah baru yang lebih besar lagi dan lebih diharapkan lagi hasil belajar yang diinginkan dapat terwujud dengan baik. Salah model pembelajaran yang diperkiran dapat dilakukan untuk mengatasi permsalahan ini adalah pembelajaran dengan menggunakan model pembelajaran mindmap. Mind-map adalah suatu teknik mencatat yang menonjolkan sisi kreativitas sehingga efektif dalam memetakan pikiran (Tony Buzan, 2004).

Toi, H., \& Perry, C. (2013) menyatakan bahwa mind mapping bisa membantu anak-anak mengingat kata-kata lebih efektif dari pada menggunakan daftar, dengan perbaikan dalam memori hingga 32\%. Lebih lanjut, Farrand, P., Hussain, F., \& Hennessy, E. (2002) menemukan bahwa pemetaan pikiran meningkatkan memori jangka panjang dari informasi faktual pada mahasiswa kedokteran sebesar 10\%. Mereka melaporkan bahwa "Mind Maps menyediakan teknik belajar efektif bila diterapkan pada bahan tertulis" dan cenderung "mendorong tingkat yang lebih dalam pengolahan" untuk pembentukan memori yang lebih baik. Selanjutnya, Holyoak, K. J. (1991) menemukan bahwa dengan mencantumkan dan menonjolkan cabang utama dalam pemahaman, seperti diberi tanda/warna awan, anda menggunakan teknik yang dikenal sebagai chunking memori. Dimana karena keterbatasan memorijangka pendek kita adalah rata-rata hanya mampu menyimpan tujuan hal informasi, maka dengan chunking dapat membantu kita menggunakan ruang penyimpanan lebih efektif dan lebih banyak.

\section{METODOLOGI}

Penelitian ini merupakan penelitian tindakan kelas (PTK) menggunakan pendekatan kualitatif yang dilakukan terhadap siswa kelas III SD Negeri 07 Situjuh Gadang Kecamatan Situjuh Limo Nagari. Penelitian ini terdiri dari dua siklus dengan Prosedur pelaksanaan mengikuti prinsipprinsip dasar penelitian tindakan kelas yang umum. Instrumen penelitian ini adalah pengawas TK/SD sebagai observer dan penulis sendiri sebagai perencana dan pelaksana pembelajaran di kelas. Data di peroleh dalam penelitian ini, dianalisis dengan menggunakan analisis data kualitatif yang ditelaah mulai dari pengumpulan data sampai seluruh data terkumpul.

\section{HASIL DAN PEMBAHASAN}

Dalam pelaksanaannya penelitian ini memilki 2 Siklus dam masing-masing siklus terdiri dari empat tahap yaitu: refleksi awal, perencanaan tindakan, pelaksanaan tindakan, dan refleksi akhir.

\section{Siklus I}

\section{A. Tahap Refleksi awal}

Berdasarkan hasil UAS I dan ulangan harian yang telah dilakukan terhadap pelajaran IPA pada Kompetensi Dasar 1.1 yang ternyata hasilnya mengecewakan, karena sebagian besar siswa tidak tuntas dalam belajar, maka timbullah keinginan dari peneliti untuk memperbaiki proses pembelajaran yang telah dilakukan. Peneliti menyadari betul banyak kekuranan dari proses pembelajaran yang telah dilakukan. Hal itu peneliti sampaikan kepada Kepala Sekolah.

Dari hasil musyawarah antara peneliti dengan Kepala sekolah SD Negeri 07 Situjuh Gadang, disepakati akan dilaksanakan penelitian tindakan kelas (PTK) terhadap kelas peneliti yang akan dilaksanakan mulai 29 Januari 2019. Disepakati dalam penelitian akan diterapkan pembelajaran Mind Map.

Selanjutnya disusunlah perencanaan, tindakan, dan observasi secara kolaborasi antara peneliti dengan observer, dalam hal ini Kepala SD N.07 Situjuah Gadang Kecamatan Situjuh Limo Nagari, yaitu Bapak RIDWAN, S.Pd.M.Pd.

\section{B. Tahap Perencanaan}

Penyusunan perencanaan meliputi: 1) Menyusun rencana tindakan berupa model pembelajaran yang meliputi berupa model pembelajaran yang meliputi tujuan pembelajaran, menetapkan materi, langkah-langkah pembelajaran, memilih dan menetapkan media, sumber belajar serta evaluasi; 2) Menyusun alat perekam data berupa lembar observasi; 3) Mendiskusikan cara pengumpulan data dalam pelaksanaan observasi saat kegiatan dilakukan. 


\section{Tahap pelaksanaan Tindakan}

Untuk siklus I pada pertemuan pertama, guru telah menyimpan rencana pelaksanaan pembelajaran (RPP) dengan model pembelajaran Mind Map. Materi yang disajikan adalah tentang "Penyesuaian diri makhluk hidup". Guru mempresentasikan materi pelajaran dengan menggunakan alat bantu ajar berupa laptop dan infokus. Di ini terlihat kalau siswa sangat tertarik dengan pembelajaran yang disajikan guru, mereka antusias sekali mengikutinya. Hal ini terjadi karena pada penyajian pelajaran, mereka bisa melihat gambar-gambar yangmenarik dan mendukung materi. Apalagi model pembelajaran ini masih baru bagi mereka.

Pada pertemuan kedua, guru menerangkan dan mencontohkan di papan tulis cara meringkas materi pelajaran dengan menggunakan model mind map. Siswa mencatat yang dicontohkan guru pada buku catatannya. Penilaian untuk siklus I juga dilakukan pada pertemuan kedua ini. Guru telah menyiapkan sebuah mind map dengan sebagian kotaknya masih kosong, siswa diminta untuk mengisinya sesuai dengan materi yang telah dipelajari sebelumnya. Hal ini bertujuan untuk melatih daya ingat siswa terhadap pelajaran. Dari hasil pengamatan dan perolehan nilai pada siklus I ini, disimpulkan bahwa terjadi peningkatan mutu dan hasil belajar tetapi ketuntasan belum mencapai seratus persen, karena itu perlu dilanjutkan pada siklus kedua.

D. Refleksi Akhir

Dari hasil evaluasi yang telah dilaksanakan pada siklus pertama, telah terlihat kenaikan grafik perolehan nilai serta jumlah siswa yang tuntas juga meningkat, walau belum semua siswa yang mengalami ketuntasan dalam belajar, hal itu terjadi mungkin karena model pembelajaran itu masih baru bagi siswa, mereka belum terlatih merangkum sendiri materi pelajaran yang mereka terima, karena selama ini gurulah yang lebih berperan menyimpulkan materi pelajaran buat mereka.

Berdasarkan kenyataan tersebut, maka dilanjutkanlah tindakan pada siklus ke-2, juga dilakukan sebanyak satu kali pertemuan.

\section{Siklus II}

\section{A. Refleksi}

Berdasarkan refleksi akhir yang dilakukan pada siklus I maka, peneliti merencabakan untuk melaksanakan semua tindak lanjut yang telah dirumuskan pada refleksi akhir pada siklus I.

B. Tahap Perencanaan

Untuk siklus II dilaksanakan pada pada Rabu tanggal 13 Februari 2019. Pada siklus II sama seperti Siklus I, juga dipersiapkan alat dan bahan yang menunjang untuk pelaksanaan kegiatan.

Dalam tahap perencanaan ini, peneliti menginterpretasikan hasil yang peneliti temui pada siklus I, yaitu sebagai berikut:

\begin{tabular}{|c|l|l|} 
Tabel 1. Hasil Penelitian Pada Siklus I dan Rencana Tindak Lanjut \\
\hline No & \multicolumn{1}{|c|}{ Temuan Pada Siklus I } & \multicolumn{1}{|c|}{ Tindak Lanjut } \\
\hline 1 & $\begin{array}{l}\text { Guru terlihat lebih aktif dari pada } \\
\text { siswa }\end{array}$ & $\begin{array}{l}\text { Semua siswa diminta membuat } \\
\text { sendiri mind map pada kertasnya } \\
\text { masing-masing pada siklus II }\end{array}$ \\
\hline 2 & $\begin{array}{l}\text { Siswa belum mahir meringkas } \\
\text { sendiri dengan mind map }\end{array}$ & $\begin{array}{l}\text { Siswa dilatih dengan cara mengisi } \\
\text { kotak yang masih rumpang pada } \\
\text { mind map yang telah disiapkan guru } \\
\text { pada pertemuan ke-2 siklus I }\end{array}$ \\
\hline 3 & $\begin{array}{l}\text { Belum semua siswa mengalami } \\
\text { ketuntasan dalam belajar }\end{array}$ & $\begin{array}{l}\text { Siswa diminta membuat sendiri } \\
\text { ringkasan materi dengan mind map } \\
\text { pada siklus II }\end{array}$ \\
\hline
\end{tabular}

\section{Pelaksanaan Tindakan}

Pertemuan pertama pada siklus II, siswa diminta meringkas materi pelajaran tentang "penyesuaian diri makhluk hidup" menggunakan model Mind Map. Dimana pada hari sebelum pembelajaran, siswa diminta membawa kertas HVS putih ukuran A4, pewarna dengan bermacam warna. 
Siswa dikelompokkan dan mereka bebas berdiskusidikelompoknya tentang model Mind Map yang akan mereka buat. Semua siswa bekerja, mereka juga bebas berkreasi menurut idenya masing-masing. Dalam membuat ringkasan materi, siswa diperbolehkan membaca buku cetak atau buku penunjang.

Pada pertemuan kedua, guru memajangkan Mind Map yang telah dibuat siswa di papan tulis. Hasil karya yang menarik dan bagus, dipajangkan pada madding kelas. Setelah itu dilanjutkan dengan penilaian dalam bentuk isian dan uraian.

\section{Reflekasi Akhir}

Setelah dilaksanakan evaluasi pada akhir siklus kedua ini, seluruh siswa telah mencapai ketuntasan dalam belajar, nilai rata-rata juga mengalami kenaikan. Terlihat juga antusiasme siswa dalam mengikuti pembelajaran.

Berdasarkan hasil penelitian yang dilakukan dalam dua siklus, maka berikut penelti tampilkan daftar hasil belajar bidang studi IPA kelas III sesudah PTK.

Tabel 2. Daftar Hasil Belajar Bidang Studi IPA Kelas III SD Negeri 07 Situjuah Gadang Kecamatan Situjuah Limo Nagari Semester II Tahun Ajaran 2018/2019 sesudah PTK.

\begin{tabular}{llll}
\hline \multirow{2}{*}{ No } & \multirow{2}{*}{ Nama } & \multicolumn{2}{l}{ Nilai } \\
\cline { 3 - 4 } & & Siklus I & Siklus II \\
\hline 1 & Sisilia Octariona & 70 & 80 \\
2 & Hafizah Aura & 80 & 100 \\
3 & Hanif Maulana & 90 & 80 \\
4 & Raihan Anugerah Pratama & 80 & 100 \\
5 & Tasya Amelia Putri & 80 & 100 \\
Jumlah & 400 & 460 \\
Rata-Rata & 80 & 81.20 \\
Nilai Tertinggi & 100 & 100 \\
Nilai Terendah & 70 & 80 \\
Jumlah Yang Tuntas & 4 & 5 \\
Persentase Ketuntasan & $80 \%$ & $81,2 \%$ \\
\hline
\end{tabular}

Berdasarkan tabel 2, maka dapat dilihat bahwa terjadi peningkatan hasil belajar pada bidang studi IPA di kelas III setelah dilaksanakannya pembelajran model mind-map.

\section{SIMPULAN DAN SARAN}

Dengan menerapkan model pembelajaran Mind Map, dapat mempermudah siswa mencatat materi pelajaran. Dengan Mind Map, memudahkan siswa mengingat kembali materi pelajaran yang telah dicatatnya. Dengan menerapkan model pembelajaran Mind Map, hasil belajar siswa dapat ditingkatkan, terbukti semua siswa telah mengalami ketuntasan dalam belajar dan rata-rata kelas juga meningkat.

Bertolak dari pengalaman penulis dalam menerapkan model Mind Map pada PTK ini, penulis berharap agar para guru pada umumnya dan guru sekolah dasar khususnya, bisa menerapkan pembelajaran Mind Map ini, karena sangat membantu guru dalam menjelaskan materi pelajaran dan membantu siswa lebih mudah mencatat dan mengingat kembali materi pelajaran yang telah dipelajarinya.

\section{DAFTAR RUJUKAN}

Buzan, Tony. 2011. Buku Pintar Mind Map. Jakarta: Gramedia Pustaka Utama.

Farrand, P., Hussain, F., \& Hennessy, E. (2002). The efficacy of themind map'study technique. Medical education, 36(5), 426-431.

Holyoak, K. J. (1991). 12 Symbolic connectionism: toward third-generation theories of expertise. Toward a general theory of expertise: Prospects and limits, 301.

Toi, H., \& Perry, C. (2013). How mind maps affect the practice of project management in SMEs. Gibaran Journal of Applied Management, 6. 